\title{
BERBAGAI ALTERNATIF PENDEKATAN PSIKOLOGIS DALAM STUDI AGAMA
}

\author{
Wardani \\ Fakultas Ushuluddin dan Humaniora \\ IAIN Antasari Banjarmasin \\ Diterima tanggal 3 Maret 2016 / Disetujui tanggal 9 Mei 2016
}

\begin{abstract}
This article is aimed to describe psychological approaches in the study of religions. Psychology provides many perspectives, such as Feudian psychoanalysis, eventhough it considered religion as pathology, also provided semantic tool to understand inner religious experiences. Another side of psychoanalysis functioned to study the development of children's religious experiences. Psychology also can be applied to study spiritual awakening, or more precisely, conversion from non-religious into religious experience, or from situation to other one. Trans-personal psychology is more concerned with therapeutic practices, but in the view of Dan Merkur, this kind of psychology should be called as "theology" rather than psychology in true sense of the word.
\end{abstract}

Kata-kunci: Psikoanalisis, patologi, psikologi terapan, terapeutik, kebangkitan spiritual

\section{Pendahuluan}

Psikologi agama dapat diterapkan untuk mengkaji fenomena-fenomena agama sejauh yang bisa dipahami secara psikologis. Meski demikian, pandangan para pengkaji agama terpolarisasi kepada dua sikap: sebagian pengkaji menganggap psikologi agama hanya akan mereduksi agama ke psikologi dan sebagian menunjukkan sikap simpatik dengan menganggap bahwa suatu kajian kritis dengan pendekatan psikologis merupakan cara untuk memurnikan agama dari penyembahan sebagai aktivitas manusia semata, tanpa melibat peran psikologis di dalamya. ${ }^{1}$

Psikologi agama, seperti halnya disiplin psikologi secara umum menjadi "payung" bagi cabangcabang kajiannya dan aliran-aliran pemikirannya dalam mengkaji agama: psikologi akademik, psikoanalisis, psikologi analitik, dan psikologi transpersonal. Pendekatan-pendekatan dalam studi psikologi terhadap agama tampak saling terpisah satu sama lain. Untuk memahami masing-masing pendekatan, perlu diketahui jawaban masing-masing pendekatan dalam konteks data dan metode. ${ }^{2}$

\section{Peran Psikologi dalam Kajian Sejarah Agama}

Sebuah pendekatan psiokologis dalam kajian sejarah agama lebih cenderung ke arah model pembacaan fenomenologis dalam studi agama secara umum yang concern tidak pada persoalan kandungan "manifest" dalam pengalaman keagamaan, melainkan pada sesuatu yang berada di luar kesadaran (unconsciousness) dalam pengalaman keagamaan, jadi sesuatu yang misterius dan lintas budaya (cross-cultural) dalam rekaman sejarah agama-agama. Dalam istilah Rudolf Otto-yang menolak teori evolusi budaya yang mengkontraskan secara rigid antara "magis" dan "agama"-pengalaman tentang 
yang suci atau "numinous" adalah karakteristik agama. ${ }^{3}$ Murid sekaligus koleganya, Söderblom, kemudian mengaitkan sesuatu yang suci tersebut dengan kitab suci yang dianggap suci bukan karena kandungannya, melainkan teksnya yang kemudian memunculkan ide tentang tuhan dalam pengalaman keagamaan. Beberapa pengkajian agama juga melakukan riset dengan menerima tesis itu, antara lain murid Söderblom sendiri, Ernst Arbman, yang menjelaskan lebih lanjut tesis ini. Menurutnya, adanya kepercayaan terhadap mitos yang diagungkan muncul karena tuhan atau dewa yang dipercayai "diturunkan" sebagai yang wujud tak terlihat yang bertanggung jawab dalam peristiwa keseharian.

Anggapan aksiomatik yang terbangun dari studi-studi agama yang berorientasi psikologi adalah bahwa orang dianggap religius karena mereka secara individual memiliki pengalaman keagamaan dalam bentuk apa pun wujudnya (tuhan, dewa, karma, dsb.). Bentuk-bentuk pengalaman keagamaan menjadi inti sesungguhnya agama, karena orang semula percaya kepada mitos, lalu menjadi keyakinan teologis, hingga terlibat dalam ritual-ritual, semuanya karena mereka memiliki pengalaman keagamaan.Ada dua orang teroritikus penting dari Swedia yang sama-sama dipengaruhi oleh Söderblom yang mengembangkan teori psikologi. Pertama, Ernst Arbman yang menyatakan bahwa berbagai keadaan pengalaman keagamaan (seperti tindakan keagamaan yang spontan dan kesatuan mistis) akan mengambil bentuk yang beragam sesuai dengan keyakinan keagamaan yang dianut. Kedua, Hjalmar Sundén yang menekankan "peran sosial" dari konteks asalnya untuk menjelaskan prilaku yang interpersonal, seperti yang dilakukan oleh pengkaji psikologi sosial. Menurutnya, dalam konteks studi agama, "peran sosial" akan lebih bisa diterapkan dibandingkan dengan menjelaskan peran nabi, shaman, tokoh mistik, dsb. Kedua teoritikus tersebut sama-sama berpendapat bahwa pengalaman keagamaan adalah prilaku (behaviour) yang dapat dipelajari, hanya saja perbedaanya apakah prilaku tersebut dikaitkan dengan keyakinan keagamaan atau peran sosialnya. ${ }^{4}$

Jadi, apa yang bisa dijelaskan psikologi dalam kajian sejarah agama? Sasaran yang dibidik lebih kepada aspek-aspek psikologis dalam agama:

\begin{tabular}{|c|c|}
\hline Sejarah Agama & Psikologi Agama \\
\hline Data: & \\
\hline 1. Kitab suci & $\Rightarrow$ Aspek psikologis \\
\hline 2. Sistem keyakinan & 1. Otto \\
\hline 3.Perilaku penganut & 2. Ernst Arbman \\
\hline 4. Ritual dan simbol & 3. Hjalmar Sundén \\
\hline 5. Alat keagamaan &
\end{tabular}

${ }^{3}$ Rudolf Otto dalam The Idea of the Holy mengemukakan konsep yang disebutnya sebagai "numinious" sebagai suatu potensi psikologis manusia beragama.Elemen yang membentuk "numinous" itu adalah; pertama, "perasaan ketergantungan" (feeling of dependence), bukan dalam pengertian fisik-natural, suatu istilah yang semula digunakan oleh Schleirmacher. Namun, Otto menolak permbedaan yang dibuatnya antara ketergantungan "absolut" dan ketergantungan "relatif", yaitu pembedaan antara ketergantungan religius dan ketergantungan lain, yang dinilai oleh Otto sebagai konsep yang tidak melihat kualitas intrinsik. Menurut Otto, "perasaan ketergantungan” tidak bisa diekspresikan, tak-terdefinisikan, kecuali oleh diri manusia yang merasakan pengalaman ketergantungan, karena ia begitu menjadi bagi yang mendasar atau elementer dari pengalaman manusia. Oleh karena itu, ia mengenalkan istilah "kesadaran akan keterciptaan/ kesadaran sebagai ciptaan" (creatureconsciousness) atau "perasaan keterciptaan" (creature-feeling), yaitu emosi yang muncul dari manusia akan keterciptaan karena ia merasa "tidak apa-apanya" (nothingness) ketika menatap wujud yang adi-kodrati yang mengatasi semua ciptaan. Dalam konteks itu, manusia merasakan adanya numen yang dialaminya sekarang, atau numen praesens dalam kasus Abraham (Ibrahīm) [lihat Genesis.xviii, 27 bagi Kristiani, atau Qashash al-Anbiyā’ berkaitan dengan cerita Nabi Ibrāhīm as, bagi Muslim], sehingga pasti ada yang "numinous", yang Suci, simpul Otto. (Lihat The Idea of the Holy: an Inquiry into the non-rational factor in the idea of the divine and its relation to the rational, trans. byJohn W. Harvey from Das Heilige (London, Oxford, \& New york: Oxford University Press, 1958), 8-11). Proses orang menemukan tuhan dalam penjelasan psikologis seperti itu karena orang mempersepsikan "yang Suci" tersebut sebagai "mysterium tremendum fascinan". (Lihat elemen-elemen dalam pengalaman psikologis manusia pada tahapan "tremendum" (The Idea, 12-23) dan "mysterium' (The Idea, 25-30), dan "fascinan" (The Idea, 30-40).

${ }^{4}$ Rudolf Otto, The Idea of the Holy, 166. 


\section{Agama Sebagai Patologi Kelompok}

Kajian psikologi agama juga diwarnai oleh aliran psikoanalisis Sigmund Freud (1856-1939). Freud mengritik validitas agama. Di sini dibedakan antara jiwa dan agama. Menurut Freud, jiwa (Inggris: spirit, Jerman: Geist) adalah suatu kekuatan intelektual yang secara obyektif ada di luar kosmos yang berpengaruh terhadap hidup, kesadaran, dan telepati. Sedangkan, agama (yang dirumuskannya dalam konteks teologi liberal Kristen dan Yahudi di abad ke-20) didefinisikan sebagai sistem yang berisi doktrin-doktrin atau ajaran dan janji-janji yang digambarkan sebagai ayah yang dihormati. Dari sini Freud kemudian menganggap magik dan agama muncul sebagai akibat kesalahan dalam memahami hakikat jiwa yang memuat berbagai harapan dan keinginan kekanak-kanakan.

Dalam tulisannya, Leonardo da Vinci and a Memory of His Childhood (1957 [1910]), Freud mengaitkan ketaatan terhadap aturan ayah dengan munculnya kepercayaan terhadap tuhan. Pertama, agama secara psikologis digambarkannya sebagai wujud psikologis seseorang di masa kecil dari ketaatan dan ketakutan terhadap ayah. "Wujud personal Tuhan, secara psikologis", tegasnya, "tidak lain dari ayah yang ditaati. Ini memberikan kepada kita bukti setiap hari bagaimana orang-orang muda kehilangan keyakinan agamanya segera ketika wewenang ayah hilang". Kedua, religiusitas secara biologis bisa dilacak, menurutnya, kepada ketidakberdayaan dan ketergantungan manusia kepada orang lain ketika kecil. Jadi, kajian agama dengan pendekatan psikologis, atau lebih tepatnya psikoanalisis Freud, melihat agama sebagai suatu kesalahan, suatu neurosis budaya yang bagi seseorang yang berpikir rasional dan realistis harus dihindari.

Ada beberapa karya Freud yang lain yang menjelaskan neurosis sebagai sumber munculnya keyakinan agama. Dalam essainya, “Obsessive Actions and Religious Practices" (1959 [1907]), ia mengaitkan antara neorusis dengan kemunculan ritus-ritus agama. Sedangkan, dalam Totem and Taboo (1958 [1913]), Freud berupaya menunjukkan bukti-bukti antropologis bahwa adanya larangan, seperti larangan berzina dalam kultur masyarakat Aborigin di Australia, adalah bentuk primitif agama yang semula muncul dari rasa takut. Aturan Oedipus-keinginan di luar sadar seorang anak laki-laki untuk membunuh ayahnya dan hasrat seksualnya terhadap ibunya—adalah bentuk evolusi agama. Jadi, Freud adalah seorang penganut evolusionisme agama. Ringkasnya, "In all cases, religion arose through the repression and symbolic displacement of unconscious guilt, where neurosis arose through the repression and symbolic displacement of sexual instincs" (Kesadaran beragama berkembangan evolutif secara psikologis dari instink seksual, lalukesalahan yang tak disadari, neurosis, hingga munculnya agama).

Karya-karyanya yang lain adalah Group Psychology and the Analysis of the Ego tentang keterkaitan psikologi individual dan kelompok, The Future of an Illusion, di mana ia memprediksikan bahwa di mana pun agama akan diabaikan ketika berhadapan dengan kemajuan sain dengan asumsi yang dibangunnya bahwa agama sebagai neuorosis manusia hanya akan menghimpit ke pinggir intelegensi yang dimiliki oleh manusia untuk menanam ilusi-ilusinya. Dalam Civilization and Its Discontents, pesimismenya terhadap agama semakin meningkat dengan mengatakan bahwa agama adalah "mass-delusion”, sesuatu yang dianggap lebih parah daripada sekadar ilusi. Namun, dalam karya yang disebut terakhir ini ia juga mengakui fungsi "sublimasi" agama ${ }^{5}$ dalam pengertian bahwa keinginan instink diijinkan oleh agama untuk disublimasikan ke tujuan-tujuan yang baik dan bernilai sosial.

Pembacaan model psikoanalisis Freud terhadap agama tidak berhenti pada sekadar pemahaman atas teks-teks Freud, sebagaimana diuraikan oleh Merkur dalam beberapa karyanya itu, melainkan mengalami perluasan dengan adanya kajian-kajian dengan berbagai pendekatan. The Other

${ }^{5}$ Ada tiga peran agama menurut Sigmund Freud; konsolasi, sosialisasi, dan sublimasi. 
Freud karya James J. DiCenso, misalnya, mencatat perkembangan pembacaan lain atas karya-karya utama Freud seperti oleh Jacques Lacan, Paul Ricoeur, Jacques Derrida, Luce Irigaray, dan Julia Kristeva. Para teoritisi ini telah menerapkan "pembacaan” yang lebih luas terhadap karya-karya Freud dan memberikan kontribusi ilmiahnya dalam memahami kembali psikoanalisis Freud. ${ }^{6}$ Salah satu kontribusi mereka yang kemudian diterapkan oleh James DiCenso adalah kategori Lacanian (Jacques Lacan) antara yang imaginer dan simbolik dalam pandangan Freud tentang agama. Karya Lacan memberikan insight tentang peran psikologi dalam agama, atau lebih tepatnya, dimensi religius dalam subjektivitas.Isu-isu religiusitas dibongkarnya dalam karya-karya Freud melalui interkoneksi antara bahasa, simbolisme, yang ideal, dan pembentukan kemampuan etik dan reflektif (berpikir) dalam subjek. ${ }^{7}$ Julia Kristeva, yang memperluas pembacaan Lacan, terutama dalam konsep tentang "subjek yang berproses", meski tidak seluruh setuju dengan tesis-tesisnya, lebih banyak mengembangkan refleksi tentang beberapa isu dan tema dalam Totem andTaboo. Ia merevisi pandangan Lacan tentang hubungan antara psikologi individual dan budaya. Ia juga mengembangkan kategori semiotik Lacan dalam memahami hakikat dan peran media bahasa dalam perkembangan individual dan kultural. Kristeva juga membuka persoalan tentang respon kritis dan transformatif terhadap struktur sosial simbolik yang ada. ${ }^{8}$

Dengan menerapkan pendekatan Lacan dan Kristeva tersebut, James J. DiCenso tidak melihat Freud sebagai sosok yang selama ini digambarkan (seperti terlalu mekanis), melainkan sebagai Freud "lain" yang memberikan pencerahan dalam persoalan tentang bagaimana agama bisa memiliki efek transformatif terhadap jiwa dan budaya manusia. Dalam refleksi penutupnya, ${ }^{9}$ misalnya, ia menyatakan bahwa dimensi-dimensi religius bisa merupakan kekuatan dari subjek yang mampu berfungsi sebagai transformasi etis dalam sistem simbol budaya (ethical transformations of subjectivity within cultural symbol systems). Antara dunia "pikiran", yang ideal, dan yang "diungkapkan", sistem simbol, selalu ada hubungan dan merupakan unsur yang membentuk subjektivitas. Dengan penjelasan seperti ini, DiCenso berharap munculnya kesadaran bahwa kita terkungkung atau terlokasi dalam bentuk-bentuk budaya seperti itu.Kesadaran itu menjadi kekuatan transformatif.

Jadi, James J. DiCenso membaca karya-karya Freud dengan interpretasi yang seluruhnya tampak berbeda dengan penggambaran yang ditimbul pasca-pembacaan yang dilakukan oleh pengkaipengkaji lain. Sekarang, apa kontribusi Freud dalam konteks kajian atau studi Islam? Pertama, dalam konteks kajian agama secara umum, Dan Merkur menilai karya Freud, terutama Moses and Monotheism (1964 [1939]), tidak memberikan kontribusi yang begitu signifikan dalam kajian modern dalam kritik Bible (Bible Criticism), seperti tesisnya tentang Musa seorang Mesir yang kemudian dibunuh Yahudi, banyak dibantah.Uraian Freud juga, menurut Merkur, terkadang tidak koheren antara satu data dengan yang lainnya. Sumbangan Feud bagi kajian agama, termasuk Islam, adalah dalam upayanya menjelaskan bahwa agama bisa dikaji melalui feomenanya yang menyembul ke permukaan (agama sebagai fenomena sosial dalam kajian sosiologis yang obyeknya sama dengan psikologi adalah behaviour, prilaku), agama sebagai sistem kepercayaan yang ilusif, dan konsep-konsepnya yang lain yang semakna.

Peran psikoanalisis terhadap agama, termasuk Islam, juga menjadi pertanyaan yang menggugah kalangan psikoanalis. Erich Fromm pada bagian terakhir bukunya, Psychoanalysis and Religion, menulis pada Bab V dengan judul yang menyolok "Is Psychoanalysis a Threat to Religion?" (Apakah Psikoanalisis Merupakan Ancaman terhadap Agama?). Erich Fromm mengemukakan fungsi psikoanalisis dalam

\footnotetext{
'James J. DiCenso, The Other Freud; Religion, Culture, and Psychoanalysis (New York: Rouledge, 1999$), 1$.

7 James J. DiCenso, The Other Freud, 14.

${ }^{8}$ James J. DiCenso, The Other Frend, 15.

'James J. DiCenso, The Other Frend, 147.
} 
studi agama adalah mengkaji agama dari aspek: pengalaman keagamaan (experiential), ilmiah-magis (scientific-magical), ritualistik, dan semantik. ${ }^{10}$ Dalam konteks terakhir (semantik), misalnya, Erich Fromm menjelaskan mungkinnya agama didekati dengan pendekatan semantik.Psikoanalisis memahami bahwa agama dan ritual sesungguhnya menggunakan bahasa yang tidak biasanya kita gunakan sehari-hari, yaitu bahasa simbolik. Esensi bahasa simbolik adalah bahwa pengalaman dalam, seperti pikiran dan perasaan, diungkapkan seakan-akan merupakan pengalaman yang bisa kita lihat. Bahasa inilah yang digunakan dalam mitos yang hidup berabad-abad lamanya atau "mimpi-mimpi" orang-orang sekeliling kita. Freud-lah yang membuat kita bisa mengkaji jenis bahasa yang terlupakan ini. Melalui kajiannya tentang bahasa mimpi, kita mengenal jenis-jenis, struktur, dan makna bahasa simbolik. Ia juga selalu menunjukkan bahwa bahwa mitos keagamaan adalah sama dengan bahasa mimpi. Jadi, dengan model telaahan psikoanalisis seperti ini, aspek sesungguhnya dari bahasa simbolik agama bisa dipahami. ${ }^{11}$

Kecuali memberi sedikit catatan kritis, Dan Merkur lebih banyak menjejer alternatif pendekatan-pendekatan psikologis yang mungkin diterapkan oleh pengkaji agama (Islam), karena psikologi agama sebagaimana psikologi umumnya diwarnai dengan aliran pemikiran (school of thought) yang, sebagaimana diingatkan oleh Merkur sendiri, dibentuk oleh data di sekeliling tokoh dan metode yang diterapkannya. Dalam konteks studi Islam, kita tentu tidak akan membicarakan keberatankeberatan teologis kalangan agamawan terhadap tesis ilmiah Freud, ${ }^{12}$ kecuali hanya keberatan ilmiah, seperti dikemukakan oleh Daniel S. Pals dalam Seven Theories of Religion. ${ }^{13}$

\section{Psikoanalisis Terapan (Applied Psychoanalysis)}

Yang dimaksud dengan psikoanalisis terapan adalah penerapan teori-teori psikoanalisis klinis untuk menangani data budaya, terutama untuk menjelaskan perkembangan yang dilalui oleh anak ketika melakukan ritual atau mempercayai suatu mitos. Psikoanalisis klasik melihat ritual dan mitos sebagai gejala patologis (penyimpangan) dalam proses kematangan psikoseksual. Tapi, psikoanalisis

${ }^{10}$ Erich Fromm, Psychoanalysis and Religion (New Haven: Yale University Press, 1950), 99.

${ }^{11}$ Erich Fromm, Psychoanalysis, 111.

${ }^{12}$ Dalam studi agama, kitab suci (scripture) merupakan elemen dasar yang tidak bisa diabaikan di samping ekspressi kulturalnya yang beragam, sehingga 'membaca' agama dalam dimensi-dimensi historisnya yang kompleks itu yang hanya dilihat oleh seorang pengkaji di lingkungan locus dan tempusnya untuk digeneralisasikan dan ditarik kesimpulan tentang hakikat agama tentu ada mengalami reduksi, seperti halnya dialami pendekatan historisisme, sosiologi, antropologi, yang hanya melihat phenomenon, bukan numen. Jika pemahaman seperti ini ditarik ke Islam, cukup dengan statemen Murtadha Muthahhari dalam beberapa tulisannya bahwa pengkajian tentang aspek apa pun dalam Islam yang mengabaikan peran alQur'an (saya kira semua agama mana pun yang menempatkan kitab suci sebagai peran sentral keagamannya) adalah dipertanyakan validitasnya. Problem inti sesungguhnya merepresentasikan problem outsider-insider, bistorian-believer, atau mu arrikh-mu imin. Akan tetapi, pernyataan Muthahhari yang mewakili agamawan tentu memiliki akar kegelisahan akademis yang kurang lebih sama yang dialami oleh kalangan pengkaji Islam non-agamawan, semisal kritik Juynboll, dan tokoh-tokoh kajian hadis lain, serta yang terakhir David S. Powers atas evolusi perkembangan hukum Islam Schacht dalam The Originof Mohammedan Jurisprudence dan An Introduction to Islamic Law bahwa hukum Islam belum terbentuk pada masa awal, masa Nabi dan sahabat ketika turunnya al-Qur'an atau sahabat generasi abad pertama hijriyah, melainkan dibentuk oleh fuqaha masa Umayah (Lihat David S. Powers, Studies in al-Qur'an and Hadith: The Formation of the Islamic Law of Inheritance, terj. Arif Maftuhin (Yogyakarta: LKiS, 2001), 1-10). Sama halnya keberatan terhadap Schacht dan Freud yang diajukan, baik oleh kalangan agamawan maupun ilmuwan, adalah pengabaian sacred text, karena reduksi sejarah atau reduksi agama ke pendekatan psikologis, sebagaimana kritik beberapa pengkaji agama, yang telah disebutkan oleh Merkur di awal tulisan ini.

${ }^{13}$ Lihat Pals, Seven Theories of Religion (Oxford: Oxford University Press, 1996), h. 80-83. Lihat juga John P. Koster, The Atheist Syndrome (Brentwood: Wolgemuth \& Hyatt Publishers Inc., 1989), 81-120. 
belakangan melihat bahwa perbedaan mitos yang dipercayai menunjukkan perbedaan interest orang pada waktu yang berbeda pula, karena mitos adalah simbol dari isu-isu yang sedang dihadapi. ${ }^{14}$

\section{Psikologi dan Kebangkitan Spiritual}

Perkembangan psikologi agama ditandai dengan "psikologi akademik" yang dirintis oleh Edwin Diller Starbuck dan William James. Keduanya memperkenalkan psikologi sebagai kajian tentang proses yang dilalui oleh seseorang yang non-religius hingga menjadi religius. Oleh karena itu, arah kajian aliran psikologi ini adalah bagaimana membedakan antara agama dan non-agama dan bagaimana mengidentifikasi fenomena psikologis yang dianggap religius yang berbeda dengan fenomena lain yang non-religius (suatu arah yang berbeda dengan psikoanalisis Freud yang melihat fenomena religius sebagai psikopatalogi). Menurut Starbuck, religiusitas atau perjalanan spiritual dimulai dengan konversi (bukan dalam pengertian "pindah agama", tapi dalam pengertian umumnya; perubahan kejiwaan postif) dan memuncak dengan pengalaman spiritual lebih jauh. Penjelasan Starbuck kemudian diperluas oleh James bahwa "keberagamaan yang sehat" berkembang secara lurus, bukan dalam proses dramatis. Baru setelah Starbuck dan James, studi-studi tentang "konversi" dikembangkan, tapi di bawah kategori teologis; (1) "konversi" sebagai perubahan dari iireligiusitas ke religiusitas; (2) perubahan dari keadaan religiusitas yang ada ke religiusitas yang lebih baik [dari konvensional ke personal]; dan (3) "konversi" sebagai pindah agama. Meskipun studi tentang konversi telah dilakukan, namum karena tujuan yang berbeda, maka studi tentang kebangkitan atau transformasi spiritual baru dilakukan ketika munculnya psikologi humanistik dan transpersonal di tahun 1960-an dan 1970-an. Di sini, Abraham Maslow [1964], pencetus psikologi humanistik, mengaitkan transformasi spiritual dengan motif tindakan. Menurut Maslow, setiap orang memiliki motif-motif atau kebutuhankebutuhan yang bersifat hirarkis yang tentu berkaitan dengan kepentingan psikologis, seperti kebutuhan akan rasa aman, kepemilikan, dan lain-lain hingga kebutuhan yang meningkat, seperti kebutuhan harga diri, keingintahuan, dan kebutuhan estetik. Maslow menggunakan istilah "aktualisasi diri" (self-actualization) untuk menyebut kebangkitan spiritual. Kebutuhan-kebutuhan yang bernilai, menurutnya, dapat dicapai dengan aktualisasi diri tersebut yang dibentuk oleh sistem kepercayaan agama. Orang yang dirinya telah teraktualisasikan bisa memiliki pengalaman mistis. ${ }^{15}$

Sesudah Maslow, Assagioli menggunakan istilah "realisasi diri" (self-realization) atau "kebangkitan spiritual" (spiritual awakening) untuk menyebut proses seseorang mengalami perubahan positif dalam pengalaman keagamaannya yang sering diawali dengan krisis pencarian makna esensial hidup. Krisis yang bisa ditandai dengan narsisme merubah seseorang menjadi lebih religius dan bermoral. Dalam istilah psikoanalisis Merkur sendiri, kebangkitan spiritual tersebut sebagai "proses manifestasi dan integrasi superego positif” yang diawali dengan munculnya suatu problem dalam hidup

${ }^{14}$ Dan Merkur, "Pscyhology of Religion", 171.

${ }^{15}$ Dan Merkur, "Pscyhology of Religion", 172. Menurut Abraham Maslow, ada 16 hirarki kebutuhan manusia yang antara lain adalah kebutuhan manusia akan aktualisasi diri yang antara lain dikaitkan dengan pengalaman puncak, seperti pengalaman mistik. Karakteristik-karakteristik lain adalah: apresiasi segar atau sering disebut dengan 'kebaruan' (newness), yaitu sikap sikap positif terhadap apa yang dihadapi, pengalaman puncak [mistis], etika, relasi interpersonal, humor, kreativitas, resistensi terhadap enkulturasi, nilai, resolusi terhadap dikotomi-dikotomi, sikap membedakan antara sarana dan tujuan, spontanitas dan penerimaan, kerendahan hati dan sikap hormat terhadap orang lain, bersikap kekeluargaan terhadap semua orang, dan imperfeksionis. Orang yang mengaktualisasikan diri juga harus bersikap otonom. Maslow mengatakan, "Finally, I must make a statement, even though it will certainly be disturbing to many theologians, philosopers, and scientists: self-actualizing individuals have more 'free-will' and are less 'determined' than average people are" (h. 135). Lihat lebih lanjut Abraham Maslow, Motivation and Personality, revised by Robert Frager, James Fadiman, Cynthia McReynolds, dan Ruth Cox (New York: Longman, 1970), 56 (hirarki kebutuhan) dan 123 (aktualisasi diri). 
seseorang (krisis eksistensial, misalnya) hingga menemukan solusi kreatif yang muncul dari pengalaman keagamaan dan mempengaruhi tindakannya. ${ }^{16}$

\section{Psikoterapi Transpersonal}

Psikoterapi transpersonal adalah salah satu cabang dari psikologi yang diterapkan dalam terapiterapi ganguan kejiwaan dengan menggunakan praktik-praktik keagamaan tertentu, seperti shalat, berdoa, dan meditasi. Bagaimanapun praktik-praktik tersebut dianggap bernilai dari segi klinis, psikoterapi tersebut hasilnya hanya diakui oleh satu agama tertentu (dalam pengertian ini "sektarian"), meski beberapa para praktisi mengadopsi praktik-praktik keagamaan yang dari berbagai agama (sinkretik). Dalam perspektif psikoterapi ini, tradisi misitisisme keagamaan secara apologetis, akhirnya, selalu diklaim sebagai terapetik (therapeutic, memiliki efek yang bisa menyembuhkan secara psikologis), seperti efek shalat tahajud bagi kesehatan mental. Menurut Merkur, tulisan-tulisan tentang ini meski berlabel "psikologi", sebaiknya disebut "teologi" saja. ${ }^{17}$

\section{Perkembangan Pengalaman Keagamaan Manusia}

Semua psikolog sepakat bahwa perkembangan pengalaman keagamaan akan berbeda sesuai dengan perbedaan umur, namun mereka berbeda pendapat tentang isi perkembangan tersebut dan lamanya. William W. Meissner membagi perkembangan pengalaman keagamaan manusia kepada 5 fase. Pertama, fase di mana individu umumnya tidak bisa membedakan antara subjek-objek. Kedua, fase yang didominasi oleh pandangan dunia pada anak-anak yang baru belajar berjalan. Di sini, figur agama yang diidealkan diperlukan untuk mengenali kedirian. Ketiga, fase di mana individu bersifat kohesif.Konsep-konsep yang dianut individu bersifat kongkret, literal, dan satu dimensi, peran figur yang otoritatif dan mitos yang antropomorpis. Agama dalam konteks itu bisa berperan dalam hal melarang atau mengijinkan. Keempat, fase di mana individu mulai menyadari adanya kekuaan di luar dirinya (superego). Otoritas yang dijadikan sandarannya mulai bervariasi, namun dalam pengambilan keputusan tidak selalu didasarkan atas pertimbangan pribadinya, tapi juga di luar dirinya. Kelima, fase kematangan di mana sistem kepercayaan agama dan tradisinya dianggap tidak bertentangan dengan ketegangan-ketegangan dan ambiguitas-ambiguitas yang dihadapi. Individu di sini menyadari akan adanya relativitas dan partikularitas keyakinan, simbol, dan ritual agama komunitasnya. ${ }^{18}$

Klasifikasi fase perkembangan pengalaman keagamaan juga dikemukakan oleh James W. Fowler: keyakinan agama yang lebih banyak diwarnai fantasi dan keimanan "intuitif-proyektif" (intuitive-projective faith) yang biasanya dimiliki oleh anak usia antara 3-7 tahun, keimanan "mitis-literal" (mythic-literal faith) pada anak atau remaja usia sekolah, dan keimanan "sintetik-kovensional" (syntheticconventional faith) pada orang dewasa. Menurut Fowler orang dewasa tidak pernal bisa mengalami perkembangan melampaui fase terakhir ini. ${ }^{19}$

\section{Psikoterapi Agama}

Psikoterapi agama dimulai sejak munculnya psikologi analitik yang dikembangkan oleh Carl G. Jung. Psikologi ini berkerja dari premis yang dibangun atas dasar sebuah pertanyaan mendasar:

\footnotetext{
${ }^{16}$ Dan Merkur, "Pscyhology of Religion", 172-3.

${ }^{17}$ Dan Merkur, "Pscyhology of Religion", 174.

${ }^{18}$ Dan Merkur, "Pscyhology of Religion", 175.

${ }^{19}$ Dan Merkur, "Pscyhology of Religion", 175.
} 
“Apakah keberagamaan secara inheren tidak mempunyai efek yang bisa menyembuhkan [therapeutic]?" Menurut Jung, manusia memiliki apa yang diistilahkannya dengan 'jiwa objektif atau 'jiwa tak-sadar kolektif yang sifatnya universal yang bisa menerima, dalam istilah Jung "sinkron" dengan, kejadian di dunia fisik. Jadi, “jiwa objektif” adalah bersifat kosmis.Jiwa tersebut terdiri dari pola-pola [archetype] yang berada di luar kesadaran manusia. Yang terlihat atau manifest dari manusia bukanlah pola-pola tersebut, melainkan gambaran mental dari pola-pola itu yang terdiri dari tiga: yang menunjukkan feminin, maskulin, atau yang jahat. Sakit kejiwaan bisa diatasi dengan psikoterapi agama melalui proses yang disebutnya sebagai 'individuasi' atau membuat jarak fisik dari gambaran pola-pola tersebut dengan melalui beberapa tahap perkembangan. Akhirnya, menurutnya, kesehatan jiwa tidak mungkin tanpa religiusitas.

Psikoanalitik Jung, terutama konsepnya tentang Diri (Self), dipengaruhi oleh ajaran Hindu tentang atman yang merupakan satu kesatuan dengan Brabman (Tuhan). Bagi Jung, diri adalah kesatuan antara yang sadar dan yang tak sadar. Oleh karena itu, psikoanalitik Jung dipandang menjadi agama sebagai psikologi (psychologized religion), tidak hanya tentang Tuhan, tapi juga semua proses kebangkitan spiritual manusia. ${ }^{20}$ Psikologi analitik Jung banyak mempengaruhi arah dalam studi agama, seperti pandangan Mircea Eliade dan Campbell tentang mitos. ${ }^{21}$

\section{Psikologi Sosial}

Psikologi sosial muncul dalam perkembangan disiplin psikologi dari kenyataan bahwa setelah era tahun 1920-an para tokoh psikologi akademik dalam risetnya tidak lagi bertumpu pada pengalaman mental sebagai data, melainkan bertumpu pada prilaku (behaviour) karena lebih mudah diakses, lebih terukur, dan objektif. Perkembangan arah metodologis ini menyebabkan psikologi mengabaikan studi agama setelah munculnya aliran behaviorisme. Aliran behaviorisme tidak bisa menjawab pertanyaanpertanyaan psikologis sekitar agama: Apakah fenomena subyektif dari agama? Mengapa orang menjadi religius? Bagaimana proses orang menjadi religius? Apakah yang dianggap sehat, tidak sehat, dan yang bisa menyembuhkan dari agama (aspek terapeutik)? Problem-problem seperti ini baru memperoleh tempat dalam kajian psikologi akademik setelah hilangnya monopoli psikologi behaviorisme di era tahun 1950-an dan munculnya psikologi sosial. Walaupun begitu, menurut Merkur, psikologi sosial tidak bisa memberikan kontribusinya yang signifikan bagi studi agama, karena beberapa alasan, a.l. bahwa data (seperti melalui quesioner dan pengalaman) dihimpun melalui kerja metode psikologi sosial saja, tidak melalui data yang dihimpun oleh pengkaji studi agama. ${ }^{22}$

Berbeda dengan psikologi akademik lontarkan ketika meneliti agama, "Aspek-aspek apa saja dari agama yang dapat dikuantifikasi secara statistik dan yang berkorelasi dengan statistik keagamaan yang lain?”, psikologi sosial mengajukan pertanyaan, "kapan, atau dalam kondisi seperti apa, orang menjadi lebih atau kurang religius?”. Benjamin Beit-Hallahmi menganggap bahwa psikologi sosial agama adalah psikologi historis, karena secara kultural dan historis ia merupakan kumpulan dari temuan-temuan terbatas tentang prilaku sosial pada abad ke-20 dan hampir seluruhnya berkaitan dengan beberapa masyarakat di Barat. Jadi, temuannya tentu saja tidak universal. Para pengkaji psikologi sosial sebagiannya adalah tokoh yang kompeten dalam studi agama, tapi sebagaian besar tidak kompeten. Kenyataan naïve dan tampak etnosentris yang ditunjukkan oleh Merkur adalah kajian

${ }^{20}$ Dan Merkur, "Pscyhology of Religion", 176-7.

${ }^{21}$ Lihat Peter Homans, "Jung, C.G.”, dalam Mircea Eliade (ed.), The Encyclopaedia of Religion (New York: Macmillan Library Refference, 1995), vol. 7, h. 210-213.

${ }^{22}$ Dan Merkur, "Pscyhology of Religion", 177. 
psikologi psikologi yang mengukur religiusitas dengan kehadiran di gereja yang tentu terbatas pada Kristen. ${ }^{23}$

Lalu, apa yang bisa disumbangkan oleh psikologi sosial dalam konteks studi agama? Psikologi sosial, misalnya, bisa menjelaskan korelasi antara religiusitas dengan harga diri, kepuasan dalam memenuhi kebutuhan hidup, optimisme, dan kontrol diri. Agama bisa dilhat sebagai faktor pengikat secara sosial, sehingga masyarakat yang religius cenderung sedikit melakukan tindakan penyimpang atau kriminal, pekerja keras, dan lebih terintegrasi dibanding masyarakat yang tidak religius. Begitu juga, psikologi sosial bisa menguji penggambaran Freud tentang Tuhan sebagai ayah yang dihormati, yang pada masyarakat sosial tertentu lebih tepat digambarkan sebagai karakter ibu. Di masyarakat Katolik, misalnya, Tuhan lebih banyak digambarkan maternal dibandingkan masyarakat Protestan. ${ }^{24}$

Gordon Allport, seorang psikolog sosial, memperkenalkan pembedaan antara sikap "intrinsik" dan "ekstrinsik" terhadap agama. Sikap "intrinsik" menjadikan agama sebagai tujuan yang menyediakan nilai dalam bertindak, sedangkan sikap "ekstrinsik" menjadikan agama sebagai sarana untuk mencapai tujuan sosial atau tujuan yang lain. Allport dalam konteks itu memberikan kontribusi dalam psikologi, khususnya untuk melihat korelasi statistik antara religiusitas dengan munculnya prasangka, sikap otoritarian, sikap tak senonoh. Prasangka, misalnya, berkorelasi dengan keberagamaan yang ekstrinsik yang lebih mementingkan fungsi sosial agama. Akan tetapi, menurut Merkur, analisis Allport tersebut mengandung bias Prostestan liberal modern, karena ajaran tentang kasih, sekali lagi menurut Merkur, bukan ajaran yang universal, melainkan lebih banyak diterapkan sekte keagamaan tertentu saja. Lagi pula, fakta juga menunjukkan kesimpulan yang bertentangan, yaitu di beberapa daerah umat Kristiani dan Yahudi yang saleh justeru tidak berikap toleran terhadap penganut-penganut agama di luar mereka. Karena semangat etnosentrisme Allport dalam analisisnya itu, orang-orang mempertanyakan pentingnya pembedaan antara yang "intrinsik" dan "ekstrinsik" itu dalam kajian psikologi agama. Jika dikatakan bahwa kualitas "intrinsik" dalam beragama itu berkorelasi dalam menjadikan seseorang sehat mental, kurang takut mati, dan sifat altruisme, apakah model keberagamaan yang "intrinsik" itu merupakan kualitas yang bisa diukur? Kritik terhadap Allport tersebut memunculkan tesis baru di samping keberagamaan bisa diidentifikasi dengan kategori "intrinsik" dan "ekstrinsik", agama juga bisa seperti kuis yang mengandung ketidakpastian dan keharusan adanya pembuktian terus-menerus. Itu artinya kandungan dalam kepercayaan dan praktik keagamaan bagi banyak orang tidak selalu tetap, sehingga kita tidak selalu bisa mengukur adanya hubungan korelatif seperti dalam kategori "intrinsik" dan "ekstrinsik" dengan pailaku-prilaku sosial pemeluknya. Orientasi ketiga dari agama inilah yang menjadi tesis Batson dan Ventis. ${ }^{25}$

Akhirnya, bertolak dari debat terakhir yang dikemukakan terhadap Allport dan beberapa debat terhadap tesis-tesis psikologi yang dikemukakan sebelumnya, Merkur mengkritik—sebagaimana halnya David Bakan, seorang psikolog humanistik—cara kerja psikologi dengan sebagian besar aliranalirannya yang melihat manusia sebagai mesin yang selalu bisa dijelaskan dengan "determinisme kausal" (bahwa selalu dihubungkan secara korelatif, sebab-akibat, dengan rigid seperti tesis Allport di atas). Kerja psikologi seperti itu sering menghasilkan kesimpulan yang ternyata bertentangan dengan kenyataan sesungguhnya yang dialami kita, tegas Merkur.

Kegelisahan Merkur tersebut_-sejauh yang bisa kita lihat-berkaitan dengan pergeseran psikologi yang sesungguhnya berada dalam wilayah soft sciences ke pembacaan model positivisme hard

${ }^{23}$ Dan Merkur, "Pscyhology of Religion", 178.

${ }^{24}$ Dan Merkur, "Pscyhology of Religion", 179.

${ }^{25}$ Dan Merkur, "Pscyhology of Religion", 179-80. 
sciences yang menetapkan standar validitas keilmiahan tidak hanya observable (bisa diamati) dan verifiable (bisa buktikan ulang), tapi juga measurable (terukur) secara statistik, seperti kecenderungan psikologi yang mengkuantifikasi datanya dan dianalisis dengan hubungan determinisme kausal yang pasti. Alihalih kepastian dalam hubungan kausal tersebut, apa yang disebut sebagai reguleritas, keteraturan, keberulangan, atau keajegan yang menjadi titik-tolak dibangunnya teori dan hukum, soft sciences yang menjadi obyek kajiannya adalah manusia juga berada di bawah hard sciences yang objek kajiannya adalah dunia fisika. Di samping itu, menjelaskan korelasi seperti antara prasangka sosial dengan keberagamaan yang ekstrinsik dalam contoh Allport sebagai fenomena yang kompleks dan multi-aspek, psikologi hanya bisa menjelaskan "kausalitasnya" dari subjektivitas psikologi saja. Ini mirip dengan kerja ilmu sejarah yang setelah menyajikan fakta-fakta sejarah (bistorical explanation) menjelaskan analisis sejarah (kajian analitik atau kritis tentang sejarah) yang dalam hubungan kausalitas berupaya mencari kaitan antara suatu event sejarah dengan faktor-faktor penyebab/ pemicunya. Berbeda dengan sajian data objektif, analisis sejarah adalah wilayah subjektif penulis sejarah. Tidak ada causal determinism, baik dalam sejarah maupun dalam psikologi ketika menjelaskan kaitan fenomena sosial manusia dengan kehidupan kejiwaannya. Manusia bukan seperti mesin yang bagian-bagiannya berkaitan, berkorelasi, secara pasti dan positif. Psikologi yang melihat manusia sebagai mesin bukanlah psikologi, melainkan fisika.

\section{Penutup}

Agama, termasuk Islam, tidak hanya sebagai wahyu (kitab suci), melainkan juga keyakinan (belief), dan ekspresi-ekspresi tingkah laku (behavior) dan budaya. Salah satu pendekatan dalam mengkaji agama adalah pendekatan psikologi yang bisa mengungkap berbagai aspek yang tidak bisa diungkap dengan pendekatan-pendekatan lain. Meskipun beberapa teori dan pendekatan psikologis tidak selalu kompatibel mengkaji agama, seperti Frued yang lebih banyak menyoroti agama sebagai patologi kelompok, namun tetap ada aspek-aspek psikologi yang bermanfaat untuk kajian agama, seperti kontribusi psikoanalisis untuk memahami gejala keagamaan dengan media semantik yang disumbangkan oleh Freud.

Berbagai pendekatan psikologi bisa diterapkan dalam kajian agama, seperti psikologi transpersonal, psikologi terapan, dan "psikologi akademik" dalam mengkaji kebangkitan spiritual. Peran psikologi dalam kajian agama sebenarnya adalah sebagai ilmu bantu untuk mengkaji berbagai aspek agama, seperti sejarah agama, dan sebagai kajian tersendiri, baik secara teoretis-akademis maupun terapan (sebagai terapi). Psikologi umum bisa menyediakan teori-teori atau pendekatanpendekatan yang relevan untuk diterapkan dalam kajian agama, baik dari psikologi behavioristik, transpersonal, strukturalis, psiko-analisis, dan sebagainya []

\section{DAFTAR PUSTAKA}

DiCenso, James J. The Other Freud; Religion, Culture, and Psychoanalysis. New York: Rouledge, 1999.

Erich Fromm. Psychoanalysis and Religion. New Haven: Yale University Press, 1950.

Homans, Peter. "Jung, C.G.”, dalam Mircea Eliade (ed.). The Encyclopaedia of Religion. New York: Macmillan Library Refference, 1995, vol. 7. 
Koster, John P. The Atheist Syndrome. Brentwood: Wolgemuth \& Hyatt Publishers Inc., 1989.

Maslow, Abraham H. Motivation and Personality, revised by Robert Frager, James Fadiman, Cynthia McReynolds, dan Ruth Cox. New York: Longman, 1970.

Merkur, Dan. "Pscyhology of Religion", John R. Hinnells (ed.). The Routledge Companion to the Study of Religion. Routledge,

Otto, Rudolf. The Idea of the Holy: An Inquiry into the Non-Rational Factor in the Idea of the Divine and Its Relation to the Rational, trans. byJohn W. Harvey from Das Heilige. London, Oxford, \& New York: Oxford University Press, 1958.

Pals, Daniel S. Seven Theories of Religion. Oxford: Oxford University Press, 1996. 